\title{
Effect of Oleophobic Films on Metal Fatigue
}

\author{
H. E. Frankel, J. A. Bennett, and W. L. Holshouser
}

(January 15, 1960)

\begin{abstract}
The fatigue strengths of a low-alloy steel, a magnesium alloy, and a copper-beryllium alloy were increased by coating the specimens with certain polar organic compounds. Also the dispersion of the results was much less for coated specimens of these materials than for clean ones. Similar tests showed no effect with titanium or 6061 aluminum alloy, and only a slight improvement for 17-7 PH stainless steel.

The full beneficial effect of the coatings was found only with compounds having a carbon chain of at least twelve, and this effect was not significantly reduced when the coated specimens were tested in water. Organic solvents (benzene and xylene) had a deleterious effect on the fatigue life of materials that were improved by oleophobic coatings.

It is suggested that the effect of the coatings is principally due to their ability to present a barrier to water and oxygen molecules.
\end{abstract}

\section{Introduction}

It is well known that environment has an important effect on the fatigue strength of metals. Lehmann [1], ${ }^{1}$ in 1926, showed that the fatigue strength of a metal was greatly influenced by various media surrounding the specimen. Gough and Sopwith [2,3] presented evidence which indicated that even the mild corrosion involved when fatigue tests were run in air affected the results.

Additional work by Ferguson and Bouton [4] verified the findings of the earlier investigations. In more recent findings, Frankel and Bennett [5] showed that an oil film increased the fatigue life of quenched and tempered low-alloy steel.

Not all environments which exclude air are beneficial, however. Karpenko [6] and Karpenko and Karlashov [7] showed that certain surface active media such as light oil +2 percent of oleic acid or water +2 percent of isopentanol can cause a reduction in the fatigue strength of structural steel. A recent review by Gilbert [8] summarizes much of the published work on corrosion fatigue.

A study of the literature revealed that, in many studies of the effect of environment, the media used were complex mixtures, not suitable for mechanism studies, and the data were valid only for a specific set of conditions involving many variables. In an effort to obtain more basic information on the effect of surface reactions on the fatigue process, the National Aeronautics and Space Administration sponsored an investigation at the National Bureau of Standards. This paper contains a report on one phase of this investigation.

Zisman and his associates [9] at the Naval Research Laboratory have made extensive investigations of the phenomena occurring at liquid-solid interfaces. As a result of this work, they found that certain classes of polar organic compounds form films on metal surfaces that are unwetted by, or are oleophobic to, all but the lowest-boiling hydrocarbons

1 Figures in brackets indicate the literature references at the end of this paper. and other nonpolar liquids. These films are also highly hydrophobic, and are known to be effective in preventing corrosion. It was thought important to determine the effect that they might have on fatigue.

\section{Materials and Testing Procedure}

Six alloys were selected for the investigation, as follows :

\begin{tabular}{|c|c|}
\hline Material & Condition \\
\hline SAE 4340 steel & $\begin{array}{l}\text { Quenched, double } \\
\text { tempered }\end{array}$ \\
\hline $\begin{array}{l}\text { Aluminum alloy } 6061- \\
\text { T6 }\end{array}$ & $\begin{array}{l}\text { Solution treated and } \\
\text { aged }\end{array}$ \\
\hline Titanium $(75-\mathrm{A})$ & Hot rolled \\
\hline 17-7 PH stainless & $\begin{array}{l}\text { Annealed (condition } \\
\text { A) }\end{array}$ \\
\hline opper $-1.75 \%$ & Solution annealed \\
\hline
\end{tabular}

beryllium

Magnesium (AZ63- Hot rolled H24)

All of the tests were conducted on rotating-beam fatigue testing machines of the R. R. Moore type, which apply pure bending moments to the test section. The machines were operated at approximately 2,000 rpm to minimize overheating effects. The specimens were machined with a smooth test section in which the longitudinal radius of curvature was held constant at $3 \frac{1}{2}$ in.; the minimum diameter was $0.310 \mathrm{in}$. for magnesium and $0.250 \mathrm{in}$. for the other materials. The straight cylindrical shanks were held in collet-type chucks in the bearing boxes of the machines. After the specimens were rough machined, they were ground to size with a 7 -in. diameter wheel, the plane of which was parallel to the length of the specimen. To avoid overheating the surface, very shallow cuts were used and the entire operation carefully controlled. The preparation of the specimens was completed by polishing in a longitudinal direction with 400 Aloxite paper in the automatic polishing device previously described [10]. 
For the tests with liquids in contact with the reduced section of the specimen, a short length of tight fitting polyethylene tubing was slipped over the cylindrical shanks. Prior to testing, the specimens were individually cleaned by agitation in three successive containers of high-purity benzene. The pieces of polyethylene tubing were cleaned in a similar manner; the specimens and tubing were kept in benzene until required for testing.

A test was run with the specimen under one of the following conditions: (1) Cleaned and dry, (2) coated with or immersed in an organic substance, or (3) immersed in water in either the clean condition or after coating with an oleophobic film. Whenever a liquid medium was used, an air bubble large enough to contact the specimen was deliberately left in the tube. The organic substances listed below were included in this study:

\section{Name}

n-Hexadecane

Xylene

Benzene

Octyl alcohol

Dodecyl alcohol

Dodecylamine..

Octadecylamine

\section{Formula}

$\mathrm{CH}_{3}\left(\mathrm{CH}_{2}\right) 14 \mathrm{CH}_{3---}$ $\mathrm{C}_{6} \mathrm{H}_{4}\left(\mathrm{CH}_{3}\right)_{2 \ldots} \ldots$ $\mathrm{C}_{6} \mathrm{H}_{6}$ $\mathrm{CH}_{3}\left(\mathrm{CH}_{2}\right)_{6} \mathrm{CH}_{2} \mathrm{OH}-$ $\mathrm{CH}_{3}\left(\mathrm{CH}_{2}\right)_{11} \mathrm{OH}_{\text {. . . }}$ $\mathrm{CH}_{3}\left(\mathrm{CH}_{2}\right)_{11} \mathrm{NH}_{2 \ldots} \ldots$ $\mathrm{CH}_{3}\left(\mathrm{CH}_{2}\right)_{17} \mathrm{NH}_{2 \ldots} \ldots$
Type

Nonpolar

Do.

Do.

Oleophobic

Do.

Do.

Do.
As this investigation was primarily concerned with surface reactions caused by fluctuating stress, no studies were made of environments more corrosive than air and water, nor of the effects of time or speed of testing.

All of the results obtained in tests at constant stress amplitude are presented in table 1 . The water and nonpolar liquids either had no significant effect or caused a decrease in fatigue life. The oleophobic films, however, caused a marked increase in fatigue life for three of the six materials investigated; namely, the steel, the magnesium alloy, and the copper-beryllium alloy. There was no significant difference in the results between specimens immersed in these substances or merely coated with them, and the results are not differentiated. The aluminum and titanium showed no effect of any of the environments, while the $17-7 \mathrm{PH}$ stainless showed only slight effect.

Coating of the specimens with dodecyl alcohol and then testing them in a tapwater environment resulted in as much improvement as was found with specimens tested in air. It was also found that tapwater had very little, if any, influence on the fatigue properties of those materials not affected by the oleophobic films. Continuous application of xylene or benzene to specimens of the first three metals listed in table 1 resulted in the poorest fatigue behavior.

Figure 1 shows a comparison of the effect of reagents having different carbon chain lengths. Apparently a length of about 12 carbon atoms provides optimum conditions with little change in fatigue life beyond this number. It can also be seen that the type of polar group does not appear to be as important as the number of carbon atoms.

The data in table 1 and figure 1 indicated that the results for specimens coated with dodecyl alcohol, dodecylamine, and octadecylamine were sufficiently similar to permit grouping for better statistical analysis. This has been done in table 2 for four materials. There were not enough specimens of the other materials to justify such an analysis. In the materials that were affected by the oleophobic films, the dispersion of the data, as measured by the coefficient of variation, was much smaller for the coated specimens than for clean ones at the same stress amplitude.

TABLE 1. Test results

\begin{tabular}{|c|c|c|c|c|c|c|c|c|c|c|c|}
\hline \multirow{3}{*}{ Material } & \multicolumn{11}{|c|}{ Median life, $10^{3}$ cycles } \\
\hline & \multirow{2}{*}{$\begin{array}{c}\text { Stress } \\
\text { amplitude }\end{array}$} & \multirow{2}{*}{ Clean } & \multicolumn{9}{|c|}{ Coatings a } \\
\hline & & & 1 & 2 & 3 & 4 & 5 & 6 & 7 & 8 & 9 \\
\hline 4340 steel_........ & $\begin{array}{c}1,000 \mathrm{psi} \\
95 \\
100 \\
115\end{array}$ & $\begin{array}{r}181 \\
83 \\
28\end{array}$ & 111 & 71 & 69 & $\begin{array}{l}86 \\
76 \\
25\end{array}$ & 141 & $\begin{array}{r}417 \\
189 \\
40\end{array}$ & 176 & 183 & $\begin{array}{r}432 \\
173 \\
37\end{array}$ \\
\hline $\mathrm{Mg} \mathrm{AZ}-63 \ldots$ & $\begin{array}{l}10 \\
12.5 \\
15\end{array}$ & $\begin{array}{r}500 \\
51 \\
17\end{array}$ & $-\cdots$ & $\begin{array}{r}246 \\
-\end{array}$ & 20 & $\begin{array}{r}430 \\
31\end{array}$ & 187 & $\begin{array}{r}1,776 \\
410 \\
12\end{array}$ & $\begin{array}{r}1.680 \\
315 \\
-\end{array}$ & $\begin{array}{r}1,543 \\
293 \\
\end{array}$ & $\begin{array}{r}1,300 \\
367 \\
\end{array}$ \\
\hline $\mathrm{Cu}-1.75 \mathrm{Be}$ & $\begin{array}{l}45 \\
50 \\
60\end{array}$ & $\begin{array}{r}258 \\
89 \\
21\end{array}$ & 108 & 58 & 62 & 92 & 151 & $\begin{array}{r}1,195 \\
248 \\
21\end{array}$ & 226 & $\begin{array}{r}1,450 \\
221\end{array}$ & $\begin{array}{r}1,320 \\
226 \\
\end{array}$ \\
\hline $\mathrm{Ti}-75 \mathrm{~A} \ldots \ldots$ & $\begin{array}{l}55 \\
75\end{array}$ & $\begin{array}{r}989 \\
13\end{array}$ & & & & - & & $\begin{array}{r}896 \\
14\end{array}$ & & & \\
\hline $\mathrm{Al} 6061-\mathrm{T} 6 \ldots$ & $\begin{array}{l}30 \\
37\end{array}$ & $\begin{array}{r}326 \\
49\end{array}$ & & 310 & - & $\begin{array}{r}317 \\
59\end{array}$ & $\cdots$ & $\begin{array}{r}350 \\
63\end{array}$ & & $\begin{array}{r}307 \\
58\end{array}$ & \\
\hline $17-7 \mathrm{PH}_{\ldots} \ldots$ & $\begin{array}{l}100 \\
115\end{array}$ & $\begin{array}{r}114 \\
52\end{array}$ & - & & - & $\begin{array}{r}114 \\
55\end{array}$ & - & $\begin{array}{r}169 \\
67\end{array}$ & & & \\
\hline $\begin{array}{l}\text { a 1. } n \text {-hexadecane } \\
\text { 2. xylene } \\
\text { 3. benzene } \\
\text { 4. tapwater } \\
\text { 5. octyl alcohol }\end{array}$ & & & & & $\begin{array}{l}\text { 6. do } \\
\text { 7. do } \\
\text { 8. oct } \\
\text { 9. do }\end{array}$ & $\begin{array}{l}\text { lecyl alc } \\
\text { ecylam } \\
\text { adecylai } \\
\text { lecyl alc }\end{array}$ & $\begin{array}{l}\text { ohol } \\
\text { ne } \\
\text { nine } \\
\text { ohol plus }\end{array}$ & water & & & \\
\hline
\end{tabular}


TABLE 2. Evaluated results

\begin{tabular}{|c|c|c|c|c|c|c|c|c|}
\hline \multirow{3}{*}{ Material } & \multirow{3}{*}{$\begin{array}{l}\text { Stress ampli- } \\
\text { tude }\end{array}$} & \multicolumn{5}{|c|}{ Fatigue test } & \multirow{2}{*}{\multicolumn{2}{|c|}{ Coefficient of variation }} \\
\hline & & \multicolumn{2}{|c|}{ Clean } & \multicolumn{3}{|c|}{ Coated b } & & \\
\hline & & $\begin{array}{l}\text { No. of } \\
\text { specimens }\end{array}$ & $\begin{array}{l}\text { Life, a No. of } \\
\text { cycles }\end{array}$ & $\begin{array}{l}\text { No. of } \\
\text { specimens }\end{array}$ & $\begin{array}{l}\text { Life, a No. of } \\
\text { cycles }\end{array}$ & $\begin{array}{l}\text { Percent } \\
\text { improve- } \\
\text { ment }\end{array}$ & Clean & Coated b \\
\hline 4340 & $\begin{array}{r}1,000 p s i \\
95 \\
100 \\
115\end{array}$ & $\begin{array}{r}11 \\
7 \\
12\end{array}$ & $\begin{array}{l}177 \times 10^{3} \\
87 \\
26.6\end{array}$ & $\begin{array}{l}6 \\
6 \\
5\end{array}$ & $\begin{array}{l}433 \times 10^{3} \\
180 \\
39\end{array}$ & $\begin{array}{c}144 \\
107 \\
46.8\end{array}$ & $\begin{array}{r}0.098 \\
.040 \\
.079\end{array}$ & $\begin{array}{r}0.015 \\
.014 \\
.030\end{array}$ \\
\hline $\mathrm{Mg} \mathrm{AZ}-63 \ldots$ & $\begin{array}{l}10 \\
12.5\end{array}$ & $\begin{array}{l}7 \\
5\end{array}$ & $\begin{array}{r}477 \\
48\end{array}$ & $\begin{array}{l}7 \\
7\end{array}$ & $\begin{array}{r}1,524 \\
337\end{array}$ & $\begin{array}{l}242 \\
603\end{array}$ & $\begin{array}{l}.059 \\
.110\end{array}$ & $\begin{array}{l}.022 \\
.038\end{array}$ \\
\hline $\mathrm{Cu}-1.75 \mathrm{Be}$ & $\begin{array}{l}45 \\
50\end{array}$ & $\begin{array}{l}5 \\
5\end{array}$ & $\begin{array}{r}272 \\
89\end{array}$ & $\begin{array}{l}5 \\
7\end{array}$ & $\begin{array}{r}1,268 \\
231\end{array}$ & $\begin{array}{l}365 \\
159\end{array}$ & $\begin{array}{l}.063 \\
.089\end{array}$ & $\begin{array}{l}.033 \\
.019\end{array}$ \\
\hline Al 6061-T6 & $\begin{array}{l}30 \\
37\end{array}$ & $\begin{array}{r}6 \\
10\end{array}$ & $\begin{array}{r}311 \\
50\end{array}$ & $\begin{array}{l}3 \\
6\end{array}$ & $\begin{array}{r}333 \\
54\end{array}$ & $\begin{array}{l}7 \\
8\end{array}$ & $\begin{array}{l}.032 \\
.076\end{array}$ & $\begin{array}{l}.048 \\
.072\end{array}$ \\
\hline
\end{tabular}

a Antilog of the log mean.

b Coated with oleophobic substances having carbon chain lengths of 12 or greater.

The data for 4340 steel are presented graphically in figure 2, and it will be noted that the vertical difference between the $\mathrm{S}-\mathrm{N}$ curves is nearly constant, as the improvement in fatigue life increases at low stresses. The approximate ranges of \pm 1 standard deviation from the means are shown in this figure, emphasizing the small dispersion of results with coated specimens.

An attempt was made to determine the number of cycles at which cracking started in at least one test of each of the materials in the clean and coated conditions. This was done by measuring the vibration of the bearing boxes: there is a marked increase in vibration when cracking starts. These measurements showed that approximately 85 to 90 percent of the total life of the specimen had been expended prior to the initiation of cracks. Thus, it can be concluded that, with the specimens used in this investigation, the improvement obtained with oleophobic coatings was primarily a measure of their effect on the initiation of a fatigue crack.

Zisman and coworkers [11] characterize an oleophobic substance as a long chain, aliphatic molecule having a polar group at one end. A consequence of this structure is a strong tendency to form tightly packed monomolecular films on various substrates. It has been pointed out that these materials offer the same degree of protection to specimens immersed in water as to those in air. Those specimens, given no protection, had generally shorter fatigue lives when tested with their surfaces partially in water. Thus, it is reasonable to assume that at least some of the effect of the oleophobic materials is due to their ability to present a barrier to water and oxygen molecules.

Likewise, the reduction in dispersion of results from coated specimens may be due to the replacement of the variable laboratory atmosphere with a reproducible oleophobic film of the substance. Similar results were obtained by Liu and Corten [12] who reported a marked reduction in scatter when they coated their specimens with vaseline.

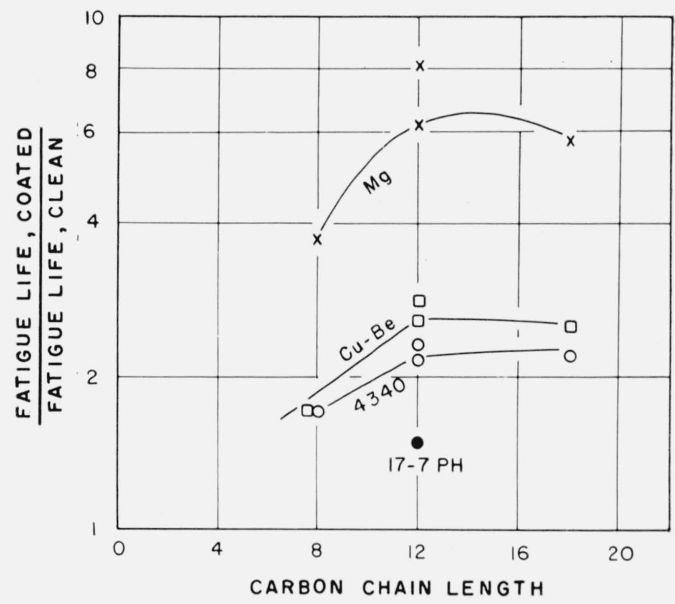

Figure 1. Effect of oleophobic films on median fatigue life for four materials.

The stress amplitudes in the tests were as follows: $\mathrm{Mg}(\mathrm{AZ}-63)-12,500 \mathrm{psi}$, SAE 4340 steel $-100,000 \mathrm{psi}, \mathrm{Cu}-1.75 \% \mathrm{Be}-50,000 \mathrm{psi}$, and $17-7 \mathrm{PH}$ stainless steel-100,000 psi. (For each material, the upper value at a chain length of 12 represents dodecyl alcohol, the lower one dodecylamine.)

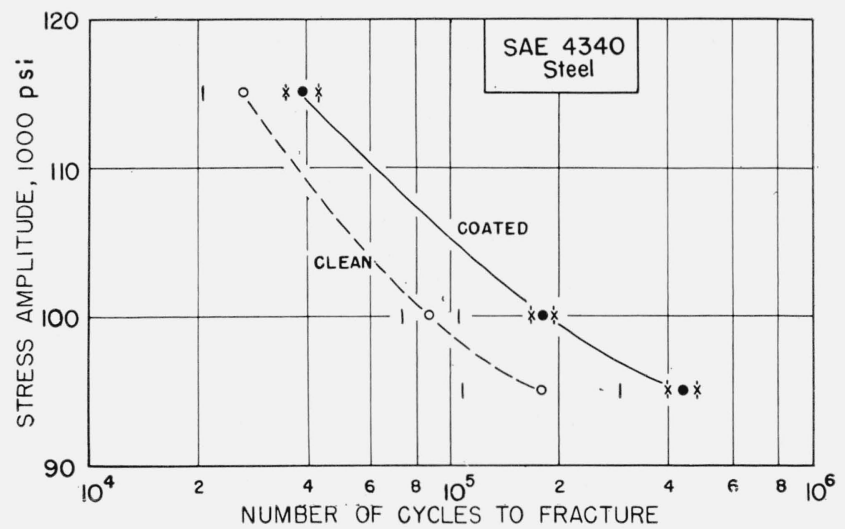

Figure 2. Number of cycles to fracture as a function of the stress amplitude for SAE 4340 steel.

Standard deviations at $\pm 1 \sigma$ are also shown. 
In contrast to the results with steel, $\mathrm{Cu}-\mathrm{Be}$ alloy, and magnesium, the fatigue strengths of the 6061 aluminum and the titanium were not affected by coatings of the oleophobic substances used. The improvement with the $17-7 \mathrm{PH}$ stainless, if any, was small. This suggests that the effects observed may be associated with the nature of the oxide film on the metals; the oxides on the unaffected alloys are known to be more adherent and less permeable than those of iron, copper, and magnesium.

On the basis of the limited data in table 1 , it appears that the organic solvents xylene and benzene have a more deleterious effect on the fatigue strength than does water. This indicates that there are phenomena other than the reactions with water and oxygen that are important in the effect of environment on fatigue, but the exact nature of these phenomena cannot be determined without additional experiments.

\section{Conclusions}

This study of the effect of certain types of polar organic substances on the fatigue life characteristics of six different alloys revealed the following:

1. A general group of organic materials which form oleophobic films on metal surfaces were found to be effective in increasing the fatigue strengths of SAE 4340 steel, AZ-63 magnesium, and a copper 1.75 percent beryllium alloy. No effect was observed with titanium (75-A) and 6061-T6 aluminum alloy, and the effect on 17-7 PH stainless steel was questionable.

Conclusions 2 to 5 apply to results on the three alloys affected by the coatings.

2. Polar compounds with carbon chain lengths of 12 and 18 produced a greater improvement in fatigue life than a compound with a chain length of 8. As two different polar groups, amines and alcohols, showed the same improvement, it seems likely that the length of the carbon chain may be one of the controlling factors.

3. The dispersion of the data from the coated specimens was much smaller than that from the clean ones tested at the same stress amplitude.

4. The mean fatigue life of specimens with oleophobic films was the same whether they were tested in water or in air.

5. With the specimens used in this investigation, the fatigue life was governed primarily by the number of cycles to initiate a crack. Thus, the improvement obtained with oleophobic coatings was largely due to increase in the number of cycles to the initiation of a fatigue crack.
6. It is suggested that oleophobic films inhibit the impingement of extraneous molecules, such as water or oxygen, upon the surface. This reduces the rate of detrimental surface reactions that normally occur when specimens are stressed in air.

The authors thank Dr. J. Kruger, National Bureau of Standards and Dr. W. A. Zisman of the Naval Research Laboratory for their assistance and advice. The magnesium alloy was supplied by Mr. I. Feinberg of the Naval Ordnance Laboratory and the copper-beryllium metal through the courtesy of the Berylium Corporation, Reading, Pa.

\section{References}

[1] G. D. Lehmann, The variation in the fatigue strength of metals when tested in the presence of various liquids. Aeronautical Research Committee, R. and M. No. 1054 (1926).

[2] H. J. Gough and D. G. Sopwith, Atmospheric action as a factor in fatigue of metals, J. Inst. Metals 49, 93 (1932).

[3] H. J. Gough and D. G. Sopwith, Some further experiments on atmospheric action in fatigue, J. Inst. Metals 56, 55 (1935).

[4] L. Ferguson and G. M. Bouton, The effect of a coating of polybutene on the fatigue properties of lead alloys, symposium on stress corrosion cracking of metals, ASTM, STP No. 64, p. 473 (1944).

[5] H. E. Frankel and J. A. Bennett, Understressing as a means of eliminating the damaging effect of fatigue stressing, Proc. ASTM 55, 891 (1955).

[6] G. Karpenko, Effect of the frequency of stress cycles upon the fatigue of steel in surface-active and in corrosive media, Doklady Akademii Nauk SSSR 87, No. 5, 797 (1952).

[7] G. V. Karpenko and A. V. Karlashov, Effect of specimen dimensions upon adsorption fatigue and corrosion fatigue in steel, Doklady Akademii Nauk SSSR 92, No. 3, 603 (1953).

[8] P. T. Gilbert, Corrosion fatigue, Met. Reviews 1, 379 (1956.)

[9] E. G. Shafrin and W. A. Zisman, Hydrophobic monolayers adsorbed from aqueous solutions, J. Colloid Sci. 4, 571 (1949).

[10] J. A. Bennett and J. G. Weinberg, Fatigue notch sensitivity of some aluminum alloys, J. Research NBS 52, 235 (May 1954). RP2495.

[11] J. E. Brophy and W. A. Zisman, Surface chemical phenomena in lubrication, The fundamental aspects of lubrication, Ann. N.Y. Acad. Sci. 53, Art. 4, 836. (June 1951).

[12] H. W. Liu and H. T. Corten, Fatigue damage during complex stress histories, Univ. of Illinois, T.A.M. Report No. 566, Submitted to National Aeronautics and Space Administration (Contract NAw-6524), (December 1958)

Washington, D.C.

(Paper 64C2-34) 